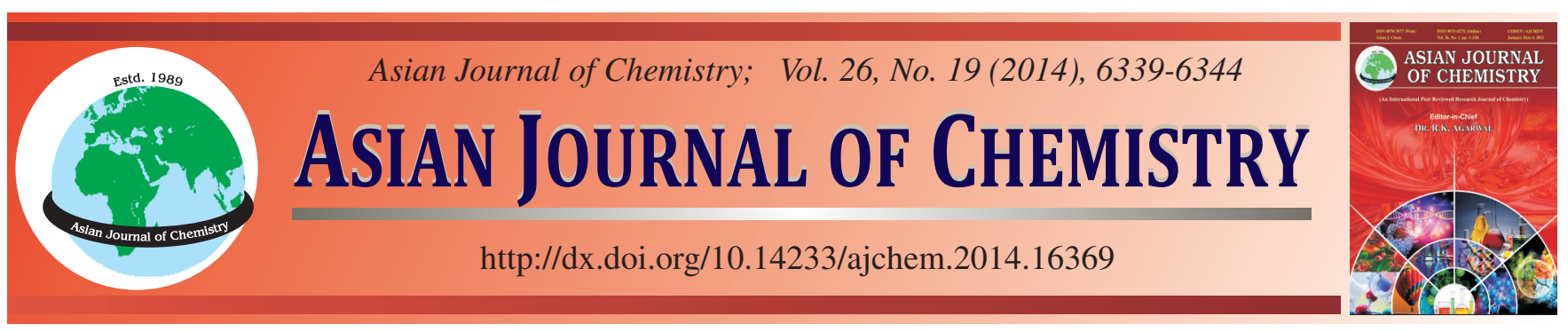

\title{
Effect of Component on Performance of Titania-Supported Selective Catalytic Reduction Denitrification Catalyst
}

Denghui Wang, Shien Hü ${ }^{*}$, Changchun Liu, Geng Zhang and YanQing Niu

School of Energy and Power Engineering, Xi'an Jiaotong University, Xi'an 710049, P.R. China

*Corresponding author: Tel: +86 15102976779; E-mail: sehui.xj@gmail.com

Published online: 16 September 2014;

AJC-15914

\begin{abstract}
Selective catalytic reduction of nitrogen oxides remains as a widely used technology scheme for reducing $\mathrm{NO}_{\mathrm{x}}$ in the flue gas from stationary sources. Investigation of the influence of composition on the performance of selective catalytic reduction flue gas denitrification $\left(\mathrm{DeNO}_{\mathrm{x}}\right)$ catalyst has great significance as catalyst technology is the core of the selective catalytic reduction process. In this research, the $\mathrm{DeNO}_{x}$ activity and selectivity of different titania-supported catalysts were tested in a small-scale experimental system. Titanium dioxide, tungsten oxide and molybdenum oxide all had denitrification effect, but the activity of these spices was low and activation temperature was high. The deposition of sulfate radical led to an increase in the $\mathrm{NH}_{3}$ adsorption but only slightly in catalytic activity. Higher vanadium loading increased the $\mathrm{DeNO}_{x}$ activity of titania-supported vanadia catalyst and lowered the activation temperature. However, more $\mathrm{N}_{2} \mathrm{O}$ was observed with the increasing of vanadium which showed that the selectivity decreased. Catalysts supported on different species of titanium dioxide had certain differences in $\mathrm{DeNO}_{x}$ performance. $\mathrm{FeSO}_{4} / \mathrm{TiO}_{2}$ was a good alternative denitration catalyst with a high $\mathrm{DeNO}_{\mathrm{x}}$ efficiency and in the temperature range of $330-420{ }^{\circ} \mathrm{C}$, the $\mathrm{NO}$ conversion rate reached $93.56-99.25 \%$ under the topical testing condition with a $\mathrm{FeSO}_{4}$ loading of 16 (wt.) \%.
\end{abstract}

Keywords: Selective catalytic reduction, $\mathrm{DeNO}_{x}, \mathrm{~N}_{2} \mathrm{O}$, Catalyst component.

\section{INTRODUCTION}

$\mathrm{NO}_{\mathrm{x}}$ emission has been a seriously environmental problem in recent years. In combustion of fossil energy in boilers, more than $95 \%$ of $\mathrm{NO}_{\mathrm{x}}$ is $\mathrm{NO}$ and the other $5 \%$ is $\mathrm{NO}_{2}$. To reduce the pollution from $\mathrm{NO}_{x}, \mathrm{NH}_{3}$-based selective catalytic reduction technology has been widely used in power plants ${ }^{1}$. In selective catalytic reduction process, the performance of denitrification $\left(\mathrm{DeNO}_{\mathrm{x}}\right)$ catalysts, such as activity and selectivity, is the most concerned part. Moreover, there is more or less $\mathrm{N}_{2} \mathrm{O}$ generated in the selective catalytic reduction process, which leads to significantly serious greenhouse effect.

The typical chemical reaction of selective catalytic reduction is reaction (1):

$$
4 \mathrm{H}_{3}+4 \mathrm{NO}+\mathrm{O}_{2} \rightarrow 4 \mathrm{~N}_{2}+6 \mathrm{H}_{2} \mathrm{O}
$$

The result of isotope label method also shows that in reaction (1), one of the two $\mathrm{N}$ atoms comes from $\mathrm{NH}_{3}$ and the other comes from NO.

If there is $\mathrm{NO}_{2}$ existing in the reaction and the ratio of $\mathrm{NO}_{2}$ and $\mathrm{NO}$ is less than $1: 1$, the chemical reaction takes place as follows ${ }^{2,3}$ :

$$
2 \mathrm{NH}_{3}+\mathrm{NO}+\mathrm{NO}_{2} \rightarrow 3 \mathrm{~N}_{2}+3 \mathrm{H}_{2} \mathrm{O}
$$

At the same temperature, the rate of reaction (2) is much higher than that of reaction (1) ${ }^{4}$. Additionally, if the ratio of
$\mathrm{NO}_{2}$ and $\mathrm{NO}$ is more than $1: 1$, redundant $\mathrm{NO}_{2}$ reacts with $\mathrm{NH}_{3}$ as reaction (3):

$$
4 \mathrm{NH}_{3}+2 \mathrm{NO}_{2}+\mathrm{O}_{2} \rightarrow 3 \mathrm{~N}_{2}+6 \mathrm{H}_{2} \mathrm{O}
$$

In the absence of oxygen, the chemical reaction of $\mathrm{NH}_{3}$ and NO takes place as follows:

$$
4 \mathrm{NH}_{3}+6 \mathrm{NO}_{2} \rightarrow 5 \mathrm{~N}_{2}+6 \mathrm{H}_{2} \mathrm{O}
$$

In the selective catalytic reduction process, side reaction (5) also takes place to generate $\mathrm{N}_{2} \mathrm{O}$ :

$$
4 \mathrm{NH}_{3}+4 \mathrm{NO}+3 \mathrm{O}_{2} \rightarrow 4 \mathrm{~N}_{2} \mathrm{O}+6 \mathrm{H}_{2} \mathrm{O}
$$

At high temperatures, $\mathrm{NH}_{3}$ could be oxidized as reaction (6), (7), (8):

$$
\begin{gathered}
2 \mathrm{NH}_{3}+3 / 2 \mathrm{O}_{2} \rightarrow \mathrm{N}_{2}+3 \mathrm{H}_{2} \mathrm{O} \\
2 \mathrm{NH}_{3}+2 \mathrm{O}_{2} \rightarrow \mathrm{N}_{2} \mathrm{O}+3 \mathrm{H}_{2} \mathrm{O} \\
2 \mathrm{NH}_{3}+5 / 2 \mathrm{NO}_{2} \rightarrow 2 \mathrm{NO}+3 \mathrm{H}_{2} \mathrm{O}
\end{gathered}
$$

As is well known, catalysts composed of different components have different $\mathrm{DeNO}_{\mathrm{x}}$ activity and selectivity. Shi et $a .^{5}$ comparatively explored the catalyst performance of fresh and hydrothermally aged Fe-ZSM-5 in standard and fast selective catalytic reduction reactions. Gao et al. ${ }^{6}$ studied the reaction kinetics of $\mathrm{Cu}-\mathrm{SSZ}-13$ catalysts with various $\mathrm{Cu}$ loadings. The adhesion and surface characteristics of monolithic $\mathrm{Cr}-\mathrm{V} / \mathrm{TiO}_{2} /$ 
cordierite catalysts were investigated for low-temperature $\mathrm{NH}_{3}$ selective catalytic reduction reactions by Huang et al. ${ }^{7}$.

Although much work has been done on the influence of catalyst states on $\mathrm{DeNO}_{\mathrm{x}}$ performance, but little attention has been paid to the impact of each component and the synergistic effect between them. In the experiments reported here, we explored the effect of different titania-supported catalytic components and the interaction effect between various components.

\section{EXPERIMENTAL}

Fig. 1 illustrates the experimental setup used in this study. Primary composition of the flue gas was supplied by cylinders containing $\mathrm{NO} / \mathrm{N}_{2}, \mathrm{NH}_{3} / \mathrm{N}_{2}, \mathrm{O}_{2}$ and $\mathrm{N}_{2}$. The relative parameters of the cylinder gas are given in Table-1. The gas flow rate is controlled by mass flowmeter and mass flowmeter was corrected by soap film flowmeter. The exhausted gas after $\mathrm{DeNO}_{\mathrm{x}}$ reaction flew into a gas analyzer through a PTFE pipe, which was heated to $105-120{ }^{\circ} \mathrm{C}$. The flue gas analyzer (GASMET FTIR D 4000 ) measures the concentrations of gases $\left(\mathrm{NO}, \mathrm{NO}_{2}\right.$, $\mathrm{N}_{2} \mathrm{O}$, etc.) to be as low as $0.2-2 \mathrm{ppm}$ and the measurement accuracy is $\pm 2 \%$.

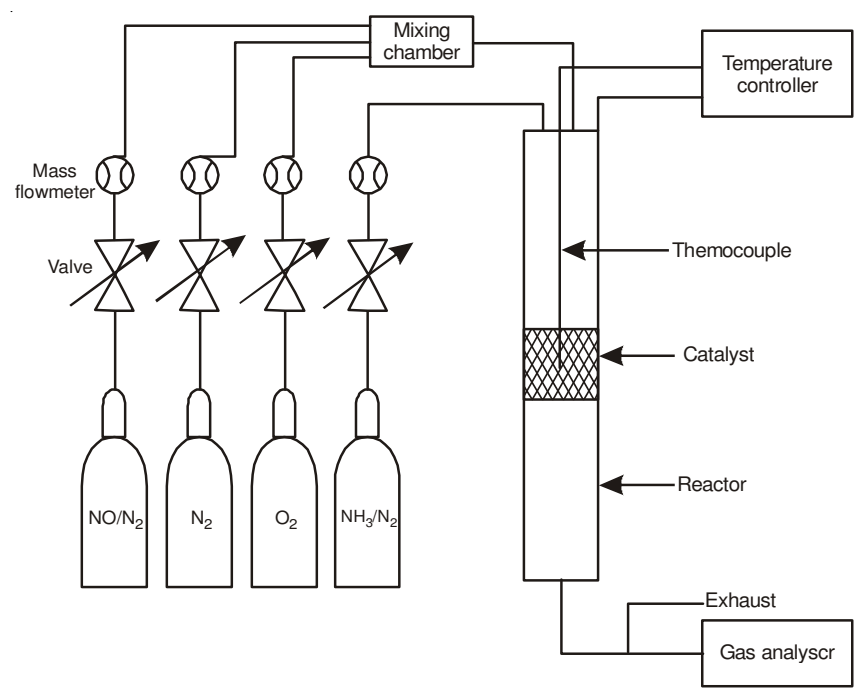

Fig. 1. Experimental setup

\begin{tabular}{cccc}
\multicolumn{4}{c}{ TABLE-1 } \\
GAS USED IN THE EXPERIMENTS \\
\hline Gas & Purity $(\%)$ & Gas & Molar ratio (\%) \\
\hline $\mathrm{N}_{2}$ & 99.999 & $\mathrm{NO} / \mathrm{N}_{2}$ & 5 \\
$\mathrm{O}_{2}$ & 99.990 & $\mathrm{NH}_{3} / \mathrm{N}_{2}$ & 5 \\
\hline
\end{tabular}

The flow rate of the total gas was kept $1 \mathrm{~L} / \mathrm{min}$ (STP, the same below), which contains $4 \% \mathrm{O}_{2}, 24 \mathrm{mmol} / \mathrm{L} \mathrm{NH}_{3}$ and 24 $\mathrm{mmol} / \mathrm{L} \mathrm{NO}$ with the balance $\mathrm{N}_{2}$.

Catalyst preparation: The catalysts tested in the experiments were sieved to 40-65 mesh particles after steeped in the same column of water, dried, calcined and ground. Usually, the mass of catalyst used in each experiment was $1 \mathrm{~g}$.

There were four kinds of titanium dioxide in the first tested group, namely 6001, 6002, 6003 and 6009 and corresponding parameters are given in Table-2.

\begin{tabular}{|c|c|c|c|c|}
\hline \multicolumn{5}{|c|}{$\begin{array}{c}\text { TABLE } 2 \\
\text { CORRESPONDING PARAMETERS OF } \\
\text { THE FOUR KINDS OF TITANIUM DIOXIDE }\end{array}$} \\
\hline & 6001 & 6002 & 6003 & 6009 \\
\hline $\mathrm{TiO}_{2}$ content (wt. \%) & 90.5 & 85.5 & 88.5 & 95.8 \\
\hline $\mathrm{WO}_{3}$ content (wt. \%) & 5.0 & 5.0 & - & - \\
\hline $\mathrm{Fe}_{2} \mathrm{O}_{3}$ content $(\mathrm{ppm})$ & 79 & 79 & - & 80 \\
\hline $\mathrm{Na}_{2} \mathrm{O}$ content $(\mathrm{ppm})$ & 74 & 82 & - & 74 \\
\hline $\mathrm{K}_{2} \mathrm{O}$ content (ppm) & 29 & 36 & - & 21 \\
\hline $\mathrm{SO}_{4}^{2-}$ content (wt. \%) & 2.4 & 2.7 & 6.18 & 2.5 \\
\hline $\mathrm{BaSO}_{4}$ content (wt. \%) & - & - & 6.8 & - \\
\hline $\mathrm{SiO}_{2}$ content (wt. \%) & - & 4.9 & - & - \\
\hline Water content (wt. \%) & 1.6 & 1.6 & - & 1.3 \\
\hline Weight loss after ignition (wt. \%) & $1.5^{\mathrm{a}}$ & $1.4^{\mathrm{a}}$ & - & $4.3^{\mathrm{b}}$ \\
\hline Specific surface area $\left(\mathrm{m}^{2} / \mathrm{g}\right)$ & 90 & 102 & 88 & 93 \\
\hline Grain size $(\mathrm{nm})$ & 16.4 & 13 & 15.8 & 16.1 \\
\hline
\end{tabular}

The second group of experimental materials were catalysts loading different content of $\mathrm{V}_{2} \mathrm{O}_{5}$ and 6009 and the mass ratios of $\mathrm{V}_{2} \mathrm{O}_{5}$ and $\mathrm{TiO}_{2}$ were $0.2,0.5,1,3,5$ and $10 \%$. The third group were catalysts loading 6009 and different content of $\mathrm{WO}_{3}$ or $\mathrm{MoO}_{3}$. The mass ratios of $\mathrm{WO}_{3}$ and $\mathrm{TiO}_{2}$ were $0.5,2$, 5 and $10 \%$, while the mass ratios of $\mathrm{MoO}_{3}$ and $\mathrm{TiO}_{2}$ were also $0.5,2,5$ and $10 \%$. The fourth group were different titania, $6001,6002,6003$ and 6009, with the same $\mathrm{V}_{2} \mathrm{O}_{5}$ and the mass ratio of $\mathrm{V}_{2} \mathrm{O}_{5}$ and $\mathrm{TiO}_{2}$ was always $1 \%$. The fifth group were 6009 catalysts with $\mathrm{FeSO}_{4}$ as active ingredient, while the sixth group were 6009 with $\mathrm{SO}_{4}{ }^{2-}$ as active ingredient.

Catalytic activity measurement: In this paper, catalytic activity and selectivity in the $\mathrm{DeNO}_{x}$ process were measured by comparing the different content of $\mathrm{NO}$ and $\mathrm{N}_{2} \mathrm{O}$ before and after the process.

NO reduction efficiency $\mathrm{X}$ is defined as:

$$
\mathrm{X}=\left(\mathrm{C}_{\mathrm{NO}}{ }^{\text {in }}-\mathrm{C}_{\mathrm{NO}}{ }^{\text {out }}\right) / \mathrm{C}_{\mathrm{NO}}{ }^{\text {in }} \times 100 \%
$$

where $\mathrm{C}_{\mathrm{NO}}{ }^{\text {in }}$ and $\mathrm{C}_{\mathrm{NO}}{ }^{\text {out }}$ refer to the $\mathrm{NO}$ concentrations at the entrance and exit of the experimental setup in a experiment condition.

The catalytic selectivity of selective catalytic reduction was measured by the generation of $\mathrm{N}_{2} \mathrm{O}$ in this research.

\section{RESULTS AND DISCUSSION}

The main component of titania is $\mathrm{TiO}_{2}$. As a kind of metal oxide, $\mathrm{TiO}_{2}$ itself has catalytic action in selective catalytic reduction reaction ${ }^{8-12}$. From Fig. 2, it could be seen that the $\mathrm{DeNO}_{\mathrm{x}}$ activity of 6001 and 6002 was extremely similar at different temperatures and it was better than that of 6003 and 6009. As the temperature increased from 320 to $420{ }^{\circ} \mathrm{C}$, the activity of all the four catalysts increased greatly. Compared with 6001,6002 contains 4.9 (wt.) $\% \mathrm{SiO}_{2}$, but the activity remained almost the same, which suggests that $\mathrm{SiO}_{2}$ is inert component in the selective catalytic reduction process. There is 5 (wt.) \% $\mathrm{WO}_{3}$ in 6001 and 6002, while there is not $\mathrm{WO}_{3}$ in 6003 and 6009 , so the difference of the reduction activity is mainly due to $\mathrm{WO}_{3}$. It is clear from Fig. 2 that the reduction activity of 6003 was a little different from that of 6009 . There is more $\mathrm{SO}_{4}{ }^{2-}$ and $\mathrm{BaSO}_{4}$ but less $\mathrm{Fe}_{2} \mathrm{O}_{3}, \mathrm{Na}_{2} \mathrm{O}$ and $\mathrm{K}_{2} \mathrm{O}$ in 6003 than in 6009 and the result here shows that $\mathrm{BaSO}_{4}$ has a low reduction activity in this experimental condition. 


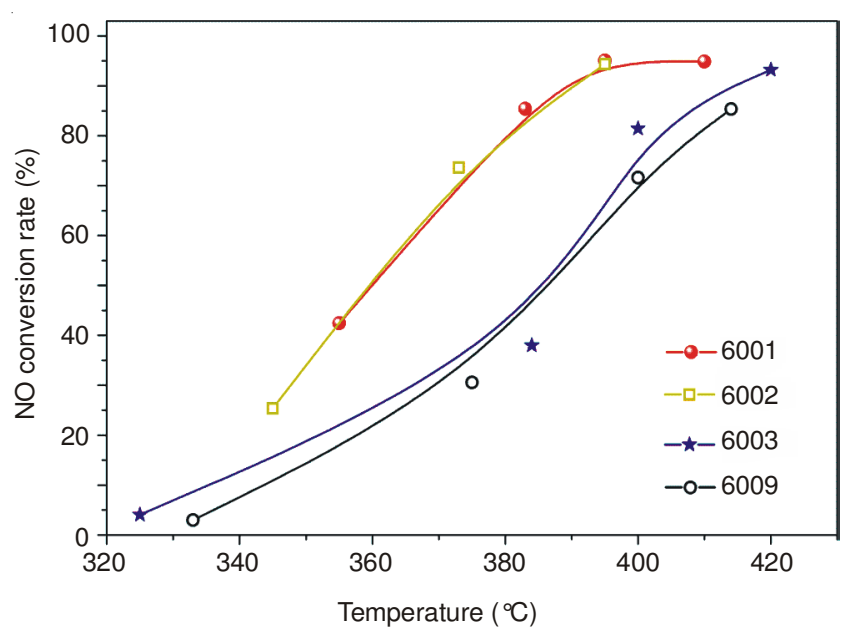

Fig. 2. DeNOx activity of titania

As shown in Fig. 3, the $\mathrm{N}_{2} \mathrm{O}$ production of 6001 raised the most at about $370{ }^{\circ} \mathrm{C}$, while the $\mathrm{N}_{2} \mathrm{O}$ production of 6003 and 6009 raised the most at about $430{ }^{\circ} \mathrm{C}$. Below $400{ }^{\circ} \mathrm{C}$, 6001 generated more $\mathrm{N}_{2} \mathrm{O}$ than 6003 and 6009 , but it generated less above $400{ }^{\circ} \mathrm{C}$. That's mainly because that there is 5 (wt.) $\% \mathrm{WO}_{3}$ in 6001, while there is not $\mathrm{WO}_{3}$ in 6003 and 6009, which indicates that although $\mathrm{WO}_{3}$ has a good reduction activity, its selectivity is poor. It can also be seen from Fig. 3 that $\mathrm{N}_{2} \mathrm{O}$ generation of the three types of titanium dioxide decreased at high temperatures (above $420{ }^{\circ} \mathrm{C}$ ). The possible reason is that as temperature rises in the reaction, the path of $\mathrm{N}_{2} \mathrm{O}$ generation is restrained, or there are other competitive reaction paths to restrict $\mathrm{N}_{2} \mathrm{O}$ generation.

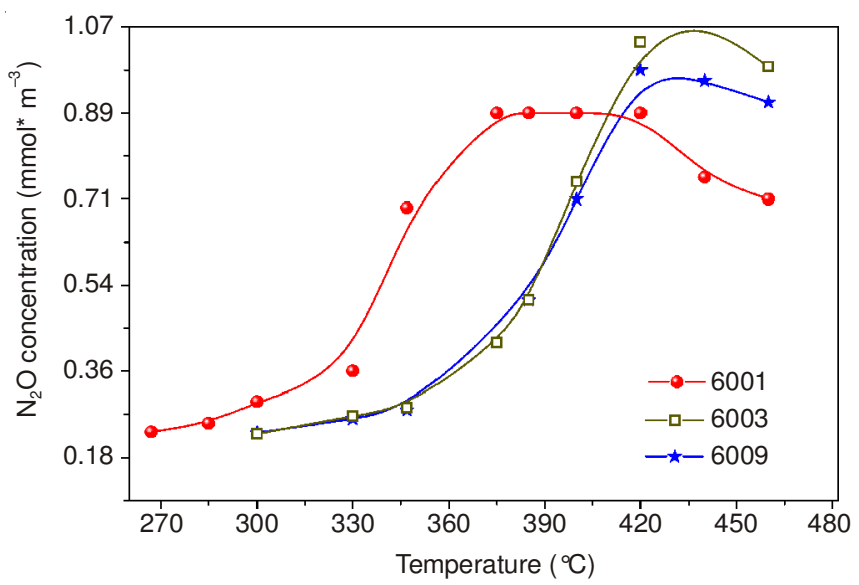

Fig. 3. DeNOx selectivity of titania

The absorption isotherms of the four kinds of titania is shown in Fig. 4, from which we could conclude that there was little difference between them and 6003 could absorb more at high pressure. Morever, when they were close to saturated absoption isotherms, there was not any absoption limitation. The pore volume of the four types of titania were tested and the differential distribution curves of logarithmic pore volume are shown in Fig. 5. Compared with 6009, there is 5 (wt.) $\%$ $\mathrm{WO}_{3}$ in 6001 and there is 5 (wt.) $\% \mathrm{WO}_{3}$ and 4.9 (wt.) $\% \mathrm{SiO}_{2}$ in 6002 , but there is not much difference in the pore size distribution of them. That shows in the range of 1-100 nm, loading $\mathrm{WO}_{3}$ or $\mathrm{SiO}_{2}$ has little influence on the pore structure.

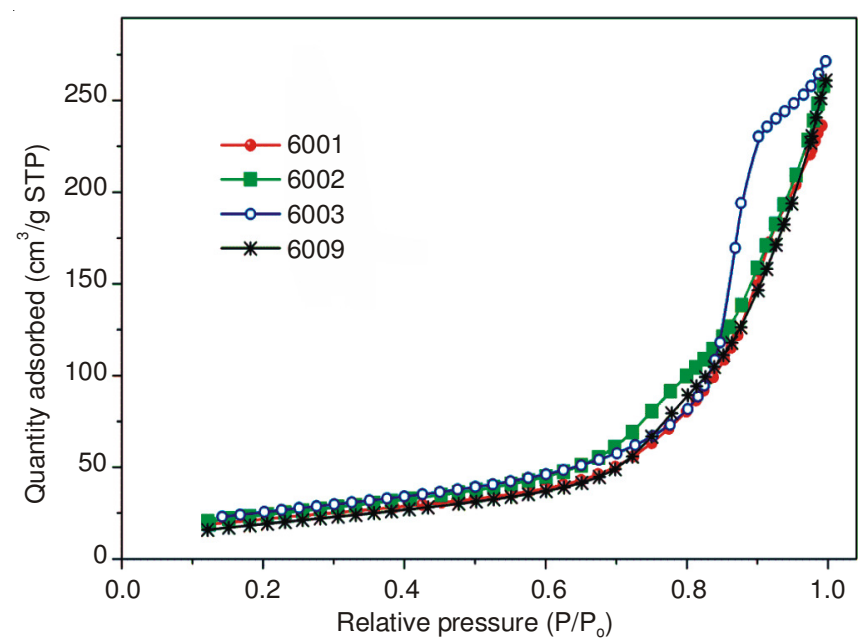

Fig. 4. Absorption isotherms of titania

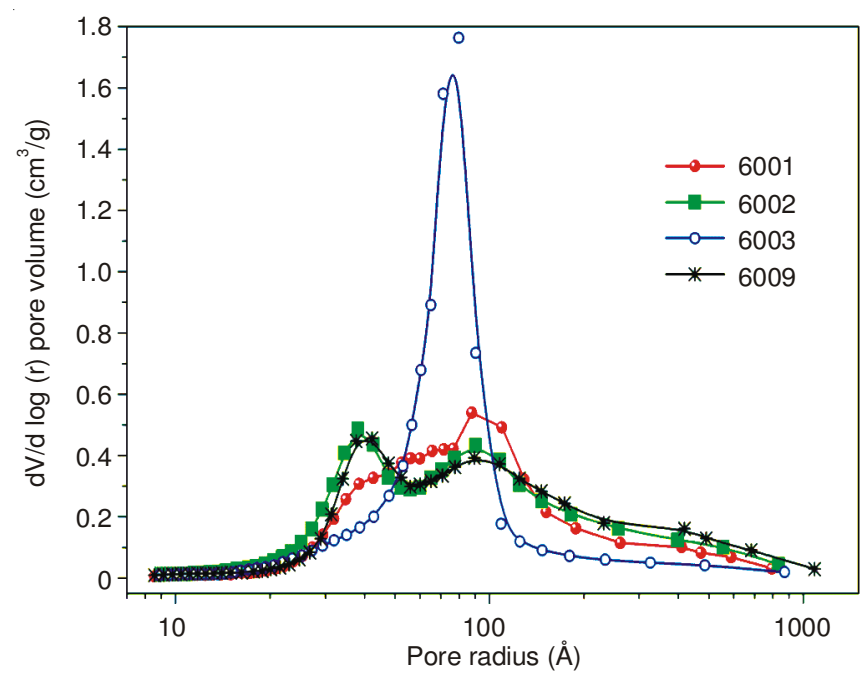

Fig. 5. Differential distribution curves of logarithmic pore volume of titania

Fig. 5 showed that the pore volumn of 6003 is quite different from the others since there is 6.8 (wt.) $\% \mathrm{BaSO}_{4}$ in it. However, the $\mathrm{DeNO}_{\mathrm{x}}$ activity of 6003 and 6009 was similar in our experiments, which shows that the pore structure in this range did not have much effect on the $\mathrm{DeNO}_{x}$ activity.

Effect of different $\mathrm{V}_{2} \mathrm{O}_{5}$ content: Oxides of $\mathrm{V}, \mathrm{Cu}, \mathrm{Fe}$, $\mathrm{Co}, \mathrm{Ni}, \mathrm{La}, \mathrm{Mn}, \mathrm{W}, \mathrm{Nb}, \mathrm{Cr}$, etc perform a certain catalytic activity at different temperature ranges in the selective catalytic reduction process ${ }^{13,14}$. Among them, $\mathrm{V}_{2} \mathrm{O}_{5}$ shows the best activity and selectivity ${ }^{15}$. As shown in Fig. 6, the NO conversation rate of titania loading $\mathrm{V}_{2} \mathrm{O}_{5}$ increased much than titania alone. Moreover, at low temperatures $\left(<350^{\circ} \mathrm{C}\right)$, the $\mathrm{NO}$ conversation rate increased as the $\mathrm{V}_{2} \mathrm{O}_{5}$ content increased. When the temperature rose above $360{ }^{\circ} \mathrm{C}$, catalyst of $1 \% \mathrm{~V}_{2} \mathrm{O}_{5} /$ $\mathrm{TiO}_{2}$ performed the greatest activity, while the activity of catalysts loading higher $\mathrm{V}_{2} \mathrm{O}_{5}$ fell down quickly.

However, the $\mathrm{N}_{2} \mathrm{O}$ production of titania loading $\mathrm{V}_{2} \mathrm{O}_{5}$ also increased much at high temperatures and more $\mathrm{V}_{2} \mathrm{O}_{5}$ promoted more $\mathrm{N}_{2} \mathrm{O}$ production. From Figs. 6 and 7, it could be concluded that $\mathrm{V}_{2} \mathrm{O}_{5}$ had a perfect reduction activity and selectivity at low reaction temperatures, but as the temperature rose the selectivity became worse and worse. The result of isotope labeling shows that the two $\mathrm{N}$ atoms of some $\mathrm{N}_{2} \mathrm{O}$ 


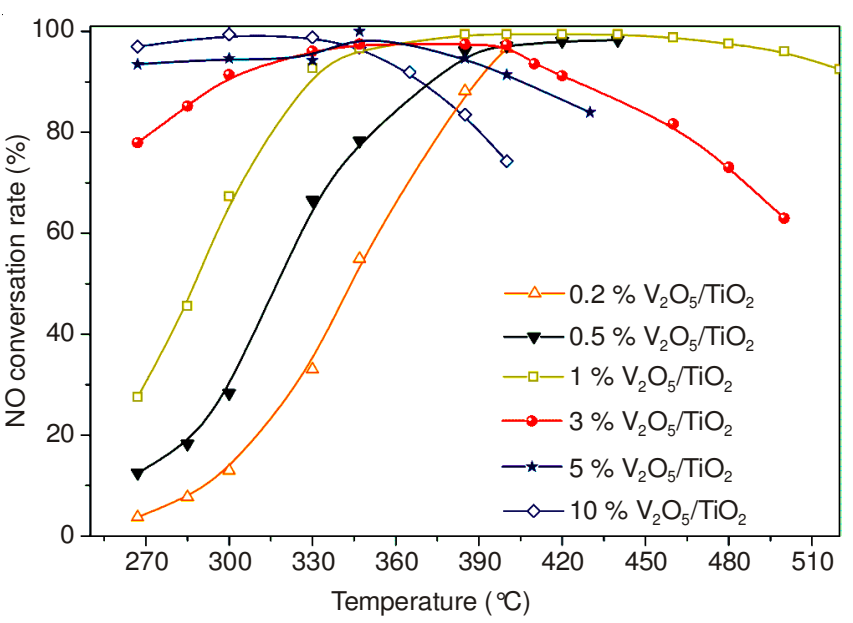

Fig. 6. DeNOx activity of titania loading $\mathrm{V}_{2} \mathrm{O}_{5}$

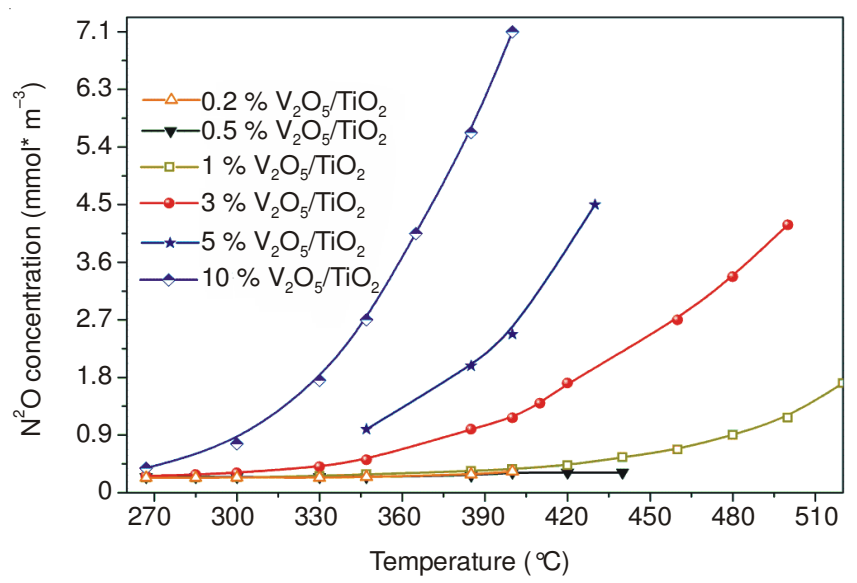

Fig. 7. DeNOx selectivity of titania loading $\mathrm{V}_{2} \mathrm{O}_{5}$

molecules come from the reaction of $\mathrm{NH}_{3}$ and $\mathrm{NO}$ (reaction (5)). The oxidation of $\mathrm{NH}_{3}$ also generates $\mathrm{N}_{2} \mathrm{O}$ [reaction (7)], but it was quite weak in this condition because of other competitive reactions. Another $\mathrm{N}_{2} \mathrm{O}$ production source was the $\mathrm{NO}$ conversion from the inlet gas and it was $0.2455 \mathrm{mmol} / \mathrm{m}^{3}$ in this experimental condition. At the same temperature, more $\mathrm{V}_{2} \mathrm{O}_{5}$ led to more $\mathrm{N}_{2} \mathrm{O}$, indicating that the greater polymerization degree of $\mathrm{V}_{2} \mathrm{O}_{5}$ on $\mathrm{TiO}_{2}$ made for the more $\mathrm{N}_{2} \mathrm{O}$ generation in selective catalytic reduction process.

Effect of $\mathrm{WO}_{3}$ and $\mathrm{MoO}_{3}$ : As shown in Fig. 8, catalysts loading $\mathrm{WO}_{3}$ could reduce $\mathrm{NO}$ efficiently, but the activation temperature was raised highly $\left(>360^{\circ} \mathrm{C}\right)$. The NO conversion rate reached the highest at about $400{ }^{\circ} \mathrm{C}$, which was similar to titania but higher than $\mathrm{V}_{2} \mathrm{O}_{5} / \mathrm{TiO}_{2}$. It was found by Kobayashi and Motonobu that increasing the content of $\mathrm{WO}_{3}$ could improve the reduction activity of $\mathrm{WO}_{3} / \mathrm{TiO}_{2}$ catalysts, which is consistent with the results here ${ }^{16}$. If the content of $\mathrm{WO}_{3}$ is lower than $40 \%$, there is not $\mathrm{WO}_{3}$ crystal existing in catalysts tested by X-Ray Diffraction, so $\mathrm{WO}_{3}$ used in our experiments was in the single decentralized state on catalysts surface.

It could be seen from Fig. 9 that different contents of $\mathrm{MoO}_{3}$ had quite different effects on the reduction efficiency and the reduction activity increase as the temperature increased. Especially, if $\mathrm{MoO}_{3}$ content was lower, the activity was affected more by temperature. As the ratio of $\mathrm{MoO}_{3}$ and $\mathrm{TiO}_{2}$ increase, the activity at low temperatures increase significantly. Compared

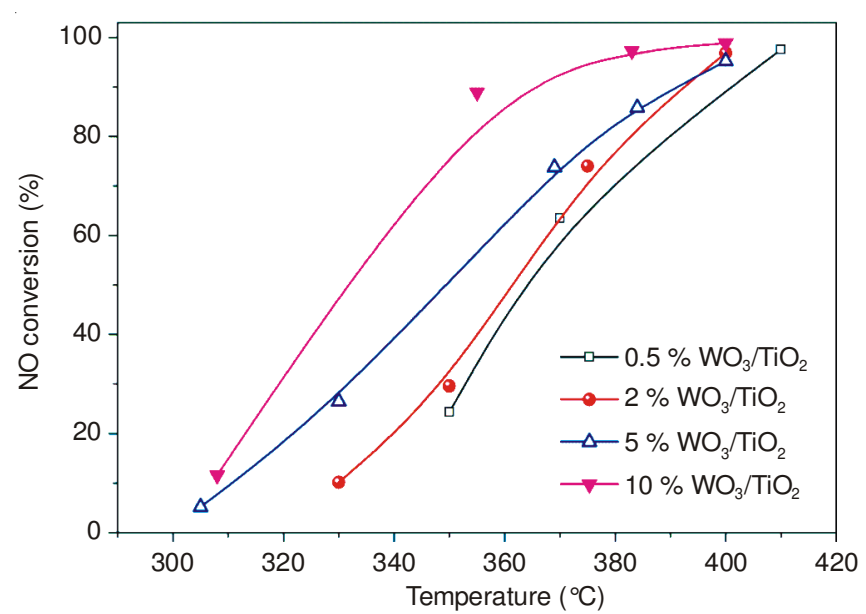

Fig. 8. DeNOx selectivity of titania loading $\mathrm{WO}_{3}$

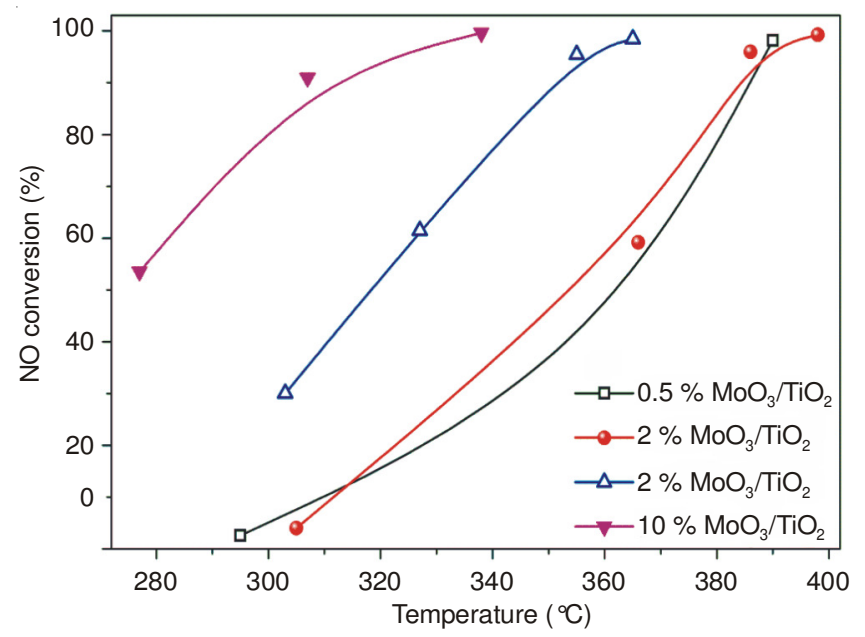

Fig. 9. DeNOx selectivity of titania loading $\mathrm{MoO}_{3}$

Figs. 8 and 9 with Fig. 6, it can be seen that the reduction activity of $\mathrm{WO}_{3}$ and $\mathrm{MoO}_{3}$ was much lower than that of $\mathrm{V}_{2} \mathrm{O}_{5}$. Adding $\mathrm{W}$ to catalysts, new W-V-Ti oxide was formed on the $\mathrm{V}$-Ti catalyst surface, so that $\mathrm{W}$ and $\mathrm{V}$-Ti could have synergistic effect to raise the reduction activity in the selective catalytic reduction process ${ }^{17}$. Additionally, the Tammann temperature of $\mathrm{WO}_{3}$ is high, so adding $\mathrm{W}$ could increase the temperature tolerance to adapt to variable working conditions ${ }^{18}$.

Effect of titania species in V/Ti catalysts: The result of the reduction activity of the fourth group (catalysts with the same $\mathrm{V}_{2} \mathrm{O}_{5}$ and different titania carrier) is shown in Fig. 10. The result of 6009 was put here for comparation, so we could see it clearly that the reduction activity of V/Ti was much better than that of 6009. Within the temperature range of 360-460 ${ }^{\circ} \mathrm{C}$, the activity difference of the four catalysts was very little and the NO conversion rate was in the range of 94-99\%. In the temperature range of $260-360{ }^{\circ} \mathrm{C}$, the activity of $\mathrm{V}_{2} \mathrm{O}_{5} /$ 6001 and $\mathrm{V}_{2} \mathrm{O}_{5} / 6002$ was higher than that of $\mathrm{V}_{2} \mathrm{O}_{5} / 6003$ and $\mathrm{V}_{2} \mathrm{O}_{5} / \mathrm{TiO}_{2}$, which was mainly because of the existence of $\mathrm{WO}_{3}$ in 6001 and 6002.

In the temperature range of $260-460{ }^{\circ} \mathrm{C}, \mathrm{N}_{2} \mathrm{O}$ generated from four kinds of V/Ti catalysts and 6009 was not much and $\mathrm{N}_{2} \mathrm{O}$ from 6009 was a little less than from the four kinds of $\mathrm{V} / \mathrm{Ti}$ catalysts. It can be seen from Fig. 11 that as temperature increased above $420{ }^{\circ} \mathrm{C}, \mathrm{N}_{2} \mathrm{O}$ generation of 6009 decreased, 


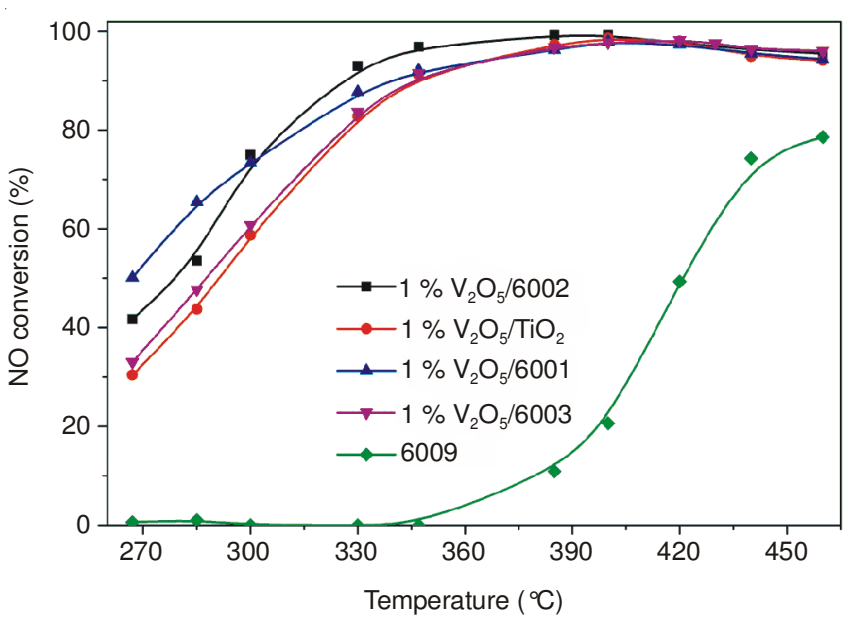

Fig. 10. DeNO $\mathrm{x}$ activity of different titania loading the same $\mathrm{V}_{2} \mathrm{O}_{5}$

which differed greatly from the result of V/Ti catalysts. The tests showed that $\mathrm{N}_{2} \mathrm{O}$ generation from catalysts containing $\mathrm{WO}_{3}$ was great, because the reduction selectivity of $\mathrm{WO}_{3}$ is poor. In this experiment, the carrier 6001 and 6002 both contain $\mathrm{WO}_{3}$, but the $\mathrm{N}_{2} \mathrm{O}$ generation amount of $\mathrm{V}_{2} \mathrm{O}_{5} / 6001$ and $\mathrm{V}_{2} \mathrm{O}_{5} /$ 6002 was not more than that of $\mathrm{V}_{2} \mathrm{O}_{5} / 6003$ and $\mathrm{V}_{2} \mathrm{O}_{5} / \mathrm{TiO}_{2}$. This can account for that the active species of catalysts is vanadium and vanadium species promoted the reduction selectivity in $260-450{ }^{\circ} \mathrm{C}$ temperature region.

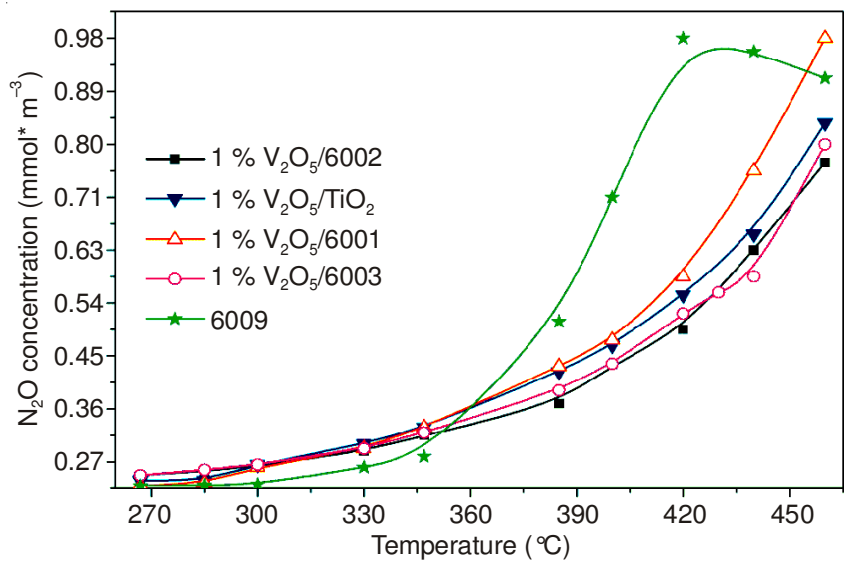

Fig. 11. DeNOx selectivity of different titania loading the same $\mathrm{V}_{2} \mathrm{O}_{5}$

DeNO $_{x}$ activity of titania-supported $\mathrm{FeSO}_{4}$ catalyst: The study of Fe-based compound for NO control includes the wet absorption method of $\mathrm{FeSO}_{4}$ solution, catalysts of molecular sieve, $\mathrm{Fe}_{2} \mathrm{O}_{3} / \mathrm{TiO}_{2}$ catalysts and so on ${ }^{19-21}$. Studies show that $\mathrm{Fe}$-based catalysts have a good denitrification effect because Fe can form variable valence oxides and both polymeric $\mathrm{Fe}$ and monomer $\mathrm{Fe}$ have reduction activity in selective catalytic reduction process ${ }^{22}$. The reason for using $\mathrm{FeSO}_{4}$ here was that the sulfate catalyst could increase the strength of acid sites on catalyst surface to promote the adsorption of ammonia and widen the temperature window of Fe-based catalyst to high-temperature region. As shown in Fig. 12, within the temperature range of $260-400{ }^{\circ} \mathrm{C}, 16 \% \mathrm{FeSO}_{4} / \mathrm{TiO}_{2}$ had the best reduction activity. However, as the temperature increased above $400{ }^{\circ} \mathrm{C}, 6 \% \mathrm{FeSO}_{4} / \mathrm{TiO}_{2}$ performed best in selective catalytic reduction process. The results showed that the most optimum ratio of $\mathrm{FeSO}_{4}$ and $\mathrm{TiO}_{2}$ was between 6 and $16 \%$.

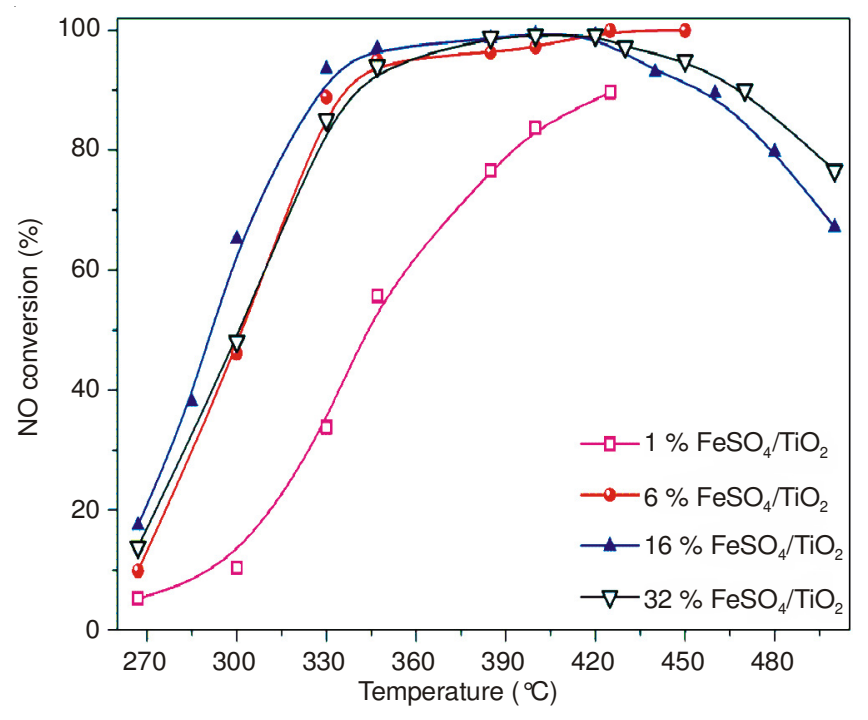

Fig. 12. DeNO activity of titania-supported $\mathrm{FeSO}_{4}$ catalyst

When the temperature was within $430-500{ }^{\circ} \mathrm{C}$, the reduction activity of $16 \% \mathrm{FeSO}_{4} / \mathrm{TiO}_{2}$ and $32 \% \mathrm{FeSO}_{4} / \mathrm{TiO}_{2}$ dropped significantly and the possible reason was that $\mathrm{NH}_{3}$ was oxidized to $\mathrm{NO}$ by $\mathrm{FeSO}_{4} / \mathrm{TiO}_{2}$ [reaction(8)].

Fig. 13 showed that little $\mathrm{N}_{2} \mathrm{O}$ was generated by $16 \%$ $\mathrm{FeSO}_{4} / \mathrm{TiO}_{2}$ and $32 \% \mathrm{FeSO}_{4} / \mathrm{TiO}_{2}$ below $430{ }^{\circ} \mathrm{C}$, but the amount increased rapidly when the temperature was above $430{ }^{\circ} \mathrm{C}$. The results showed that the reduction selectivity of $\mathrm{FeSO}_{4}$ was better at lower temperatures, but it got worse as temperature increased.

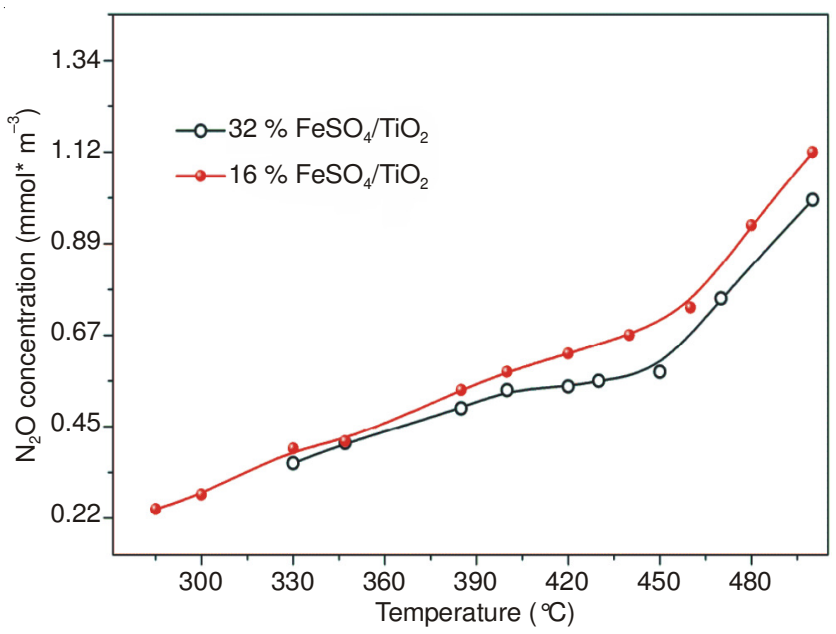

Fig. 13. DeNO x selectivity of titania-supported $\mathrm{FeSO}_{4}$ catalyst

DeNO $_{\mathrm{x}}$ activity of catalysts loading $\mathrm{SO}_{4}{ }^{2-}$ : The testing results of sulfate radical supported catalysts are shown in Fig. 14, where it is observed that the activity of catalysts with $\mathrm{SO}_{4}{ }^{2-}$ was slightly higher than that of 6009 , but the difference was not big. It is also observed that impregnated in $\mathrm{H}_{2} \mathrm{SO}_{4}$, $\left(\mathrm{NH}_{4}\right)_{2} \mathrm{SO}_{4}$ or $\mathrm{Ti}\left(\mathrm{SO}_{4}\right)_{2}$ solution, the catalysts loading sulphate had a similar reduction activity. It was similar to catalyst loading 5 (wt.) $\% \mathrm{WO}_{3}$, but less than catalyst loading 5 (wt.) $\% \mathrm{MoO}_{3}$, letting alone with $\mathrm{V} / \mathrm{Ti}$ catalysts.

Chen and $\mathrm{Yang}^{23}$ reported that $\mathrm{SO}_{4}{ }^{2-} / \mathrm{TiO}_{2}$ catalysts by $\mathrm{SO}_{2}$ treatment had a great denitration activity at high temperatures $\left(500-550^{\circ} \mathrm{C}\right)$. But this study showed that although the activity 


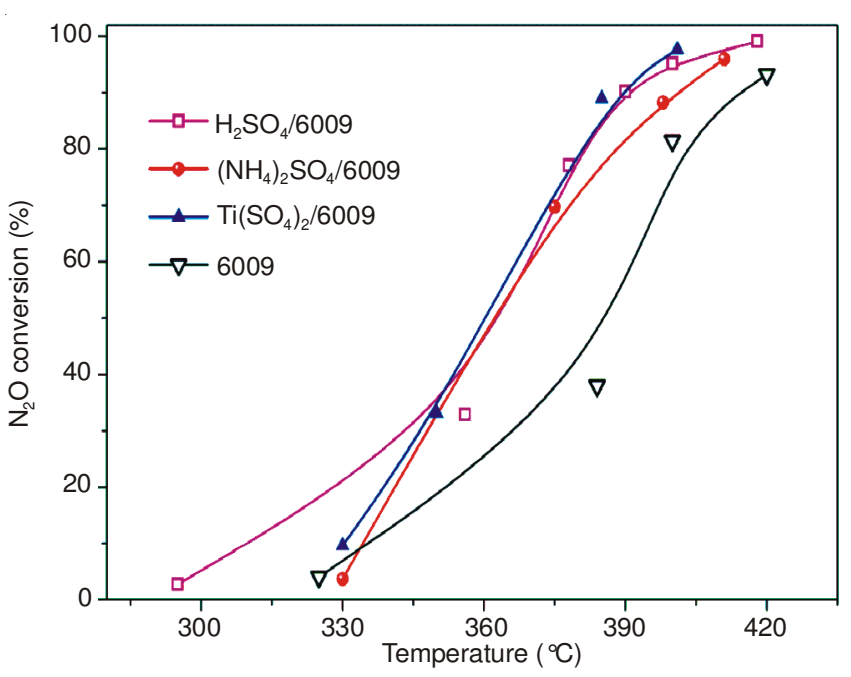

Fig. 14. DeNO activity of catalysts with $\mathrm{SO}_{4}{ }^{2-}$

of catalysts with $\mathrm{SO}_{4}{ }^{2-}$ was better than that of titanium dioxide, the activity remained weak. The existence of $\mathrm{SO}_{4}{ }^{2-}$ increases the amount of acid sites on catalyst surface and the stability of acid sites at high temperatures, but no suitable reaction sites can not ensure a high denitrification activity.

Using the specific carrier, Choo et al. ${ }^{24}$ found that the saturated amount of sulfate loading on the catalyst surface was 1-1.2 (wt.) \% (calculated at S content). A number of investigators have reported that the final sulfate species were the same regardless of the loading mode ${ }^{25-27}$. This study also found that whether steeped in $\mathrm{H}_{2} \mathrm{SO}_{4},\left(\mathrm{NH}_{4}\right)_{2} \mathrm{SO}_{4}$ or $\mathrm{Ti}\left(\mathrm{SO}_{4}\right)_{2}$ solution, the $\mathrm{DeNO}_{\mathrm{x}}$ activity of catalysts loading sulfate remained almost the same.

\section{Conclusion}

The $\mathrm{DeNO}_{x}$ activity and selectivity of different titaniasupported catalysts were tested in a small-scale experimental system. The results show that titania had a low catalytic activity of $\operatorname{DeNO}_{x}$, but much $\mathrm{N}_{2} \mathrm{O}$ was generated during the experiments. With $\mathrm{V}_{2} \mathrm{O}_{5}$, the activity of catalysts was enhanced greatly and the amount of $\mathrm{N}_{2} \mathrm{O}$ decreased at the same DeNO activity as titania. Catalysts with $\mathrm{WO}_{3}$ could reduce $\mathrm{NO}$ quite efficiently, but the activation temperature was raised highly $\left(>360{ }^{\circ} \mathrm{C}\right.$ ). Different contents of Mo had different effects on the $\mathrm{DeNO}_{\mathrm{x}}$ efficiency. If Mo content was lower, the catalyst activity was affected more by the temperature.

By testing the activity of catalysts loading the same $\mathrm{V}_{2} \mathrm{O}_{5}$ and different titania, it could be concluded that within the temperature range of $360-460{ }^{\circ} \mathrm{C}$, the activity difference of the four catalysts was very little and the NO conversion rate was in the range of 94-99\%. But within the temperature range of $260-360{ }^{\circ} \mathrm{C}$, the activity of $\mathrm{V}_{2} \mathrm{O}_{5} / 6001$ and $\mathrm{V}_{2} \mathrm{O}_{5} / 6002$ was higher than that of $\mathrm{V}_{2} \mathrm{O}_{5} / 6003$ and $\mathrm{V}_{2} \mathrm{O}_{5} / \mathrm{TiO}_{2}$. For titaniasupported $\mathrm{FeSO}_{4}$ catalyst, the most optimum ratio of $\mathrm{FeSO}_{4}$ and $\mathrm{TiO}_{2}$ was between 6 and $16 \%$. Little $\mathrm{N}_{2} \mathrm{O}$ was generated by $\mathrm{FeSO}_{4} / \mathrm{TiO}_{2}$ catalysts below $430{ }^{\circ} \mathrm{C}$, but the amount increased rapidly when the temperature was above $430{ }^{\circ} \mathrm{C}$. But impregnated in $\mathrm{H}_{2} \mathrm{SO}_{4},\left(\mathrm{NH}_{4}\right)_{2} \mathrm{SO}_{4}$ or $\mathrm{Ti}\left(\mathrm{SO}_{4}\right)_{2}$ solution, the catalysts loading sulphate had a similar reduction activity and it was similar to catalysts with 5 (wt.) $\% \mathrm{WO}_{3}$.

The tests showed that $\mathrm{N}_{2} \mathrm{O}$ generation by catalysts containing $\mathrm{WO}_{3}$ was great, because the $\mathrm{DeNO}_{\mathrm{x}}$ selectivity of $\mathrm{WO}_{3}$ is poor. In this experiment, the carrier 6001 and 6002 both contain $\mathrm{WO}_{3}$, but the $\mathrm{N}_{2} \mathrm{O}$ generation amount of $\mathrm{V}_{2} \mathrm{O}_{5} / 6001$ and $\mathrm{V}_{2} \mathrm{O}_{5} / 6002$ was not more than that of $\mathrm{V}_{2} \mathrm{O}_{5} / 6003$ and $\mathrm{V}_{2} \mathrm{O}_{5} /$ $\mathrm{TiO}_{2}$. This can account for that the active species of catalysts is $\mathrm{V}$ and $\mathrm{V}$ species promoted the reduction selectivity in the temperature range of $260-450{ }^{\circ} \mathrm{C}$.

\section{ACKNOWLEDGEMENTS}

The work was supported by the National Key Technology R \& D Program of China (Contract 2011BAK06B04) and the National Energy Application Technology Study and Demonstration Project of China (Contract NY2013040303).

\section{REFERENCES}

1. S. Eswaran and H.G. Stenger, Fuel Process. Technol., 89, 1153 (2008).

2. D.E. Doronkin, S. Fogel, S. Tamm, L. Olsson, T.S. Khan, T. Bligaard, P. Gabrielsson and S. Dahl, Appl. Catal. B, 113-114, 228 (2012).

3. I. Malpartida, O. Marie, P. Bazin, M. Daturi and X. Jeandel, Appl. Catal. B, 113-114, 52 (2012).

4. M.L.M. Oliveira, C.M. Silva, R. Moreno-Tost, T.L. Farias, A. JiménezLópez and E. Rodríguez-Castellón, Energy Convers. Manage., 52, 2945 (2011).

5. X.Y. Shi, F.D. Liu, L.J. Xie, W.P. Shan and H. He, Environ. Sci. Technol., 47, 3293 (2013).

6. F. Gao, E.D. Walter, E.M. Karp, J.Y. Luo, R.G. Tonkyn, J.H. Kwak, J. Szanyi and C.H. Peden, J. Catal., 300, 20 (2013).

7. H.F. Huang, L.L. Jin, H.F. Lu, H. Yu and Y.J. Chen, Catal. Commun., 34, 1 (2013).

8. G.T. Went, Studies of Supported Vanadium Oxide Catalysts for the Selective Catalytic Reduction of Nitrogen Oxides, University of California, Berkeley, California, United States (1991).

9. G.L. Bauerle, S.C. Wu and K. Nobe, Ind. Eng. Chem. Prod. Res. Dev., 17, 117 (1978).

10. F. Nakajima and I. Hamada, Catal. Today, 29, 109 (1996).

11. T. Shikada, K. Fujimoto, T. Kunugi, H. Tominaga, S. Kaneko and Y. Kubo, Ind. Eng. Chem. Prod. Res. Dev., 20, 91 (1981).

12. I.M. Pearson, H. Ryu, W.C. Wong and K. Nobe, Ind. Eng. Chem. Prod. Res. Dev., 22, 381 (1983)

13. H. Bosch and F. Janssen, Preface. Catal. Today, 2, v (1988).

14. H. Bosch and F. Janssen, Catal. Today, 2, 403 (1988).

15. V.I. Pârvulescu, P. Grange and B. Delmon, Catal. Today, 46, 233 (1998).

16. M. Kobayashi and K. Miyoshi, Appl. Catal. B, 72, 253 (2007).

17. K. Bourikas, C. Fountzoula and C. Kordulis, Langmuir, 20, 10663 (2004).

18. L. Lietti, J.L. Alemany, P. Forzatti, G. Busca, G. Ramis, E. Giamello and F. Bregani, Catal. Today, 29, 143 (1996).

19. S. Bosio, A. Ravella, G.B. Saracco and G. Genon, Ind. Eng. Chem. Process Des. Dev., 24, 149 (1985).

20. R.Q. Long and R.T. Yang, J. Catal., 194, 80 (2000).

21. R.Q. Long and R.T. Yang, J. Catal., 207, 158 (2002).

22. M.S. Kumar, M. Schwidder, W. Grunert and A. Brückner, J. Catal., 227, 384 (2004).

23. J.P. Chen and R.T. Yang, J. Catal., 139, 277 (1993).

24. S.T. Choo, I.-S. Nam, S.-W. Ham and J.-B. Lee, Korean J. Chem. Eng., 20, 273 (2003).

25. T. Yamaguchi, T. Jin and K. Tanabe, J. Phys. Chem., 90, 3148 (1986).

26. T. Jin, M. Machida, T. Yamaguchi and K. Tanabe, Inorg. Chem., 23, 4396 (1984).

27. T. Jin, T. Yamaguchi and K. Tanabe, J. Phys. Chem., 90, 4794 (1986). 